\title{
Adult Behind the Stage: A Narratology Study of Children Role Shaping in the Treasure Boat
}

\author{
Qi Lu ${ }^{1, *}$, , Liyao Liang ${ }^{2, \dagger}$ \\ ${ }^{1}$ School of Chinese Language and Literature, Hefei Normal University, Hefei, 230061, Anhui, China \\ ${ }^{2}$ School of Chinese Language and Literature, South China University, Guangzhou, 510631, Guangdong, China \\ *Corresponding author.Email: luqi@m.scnu.edu.cn.
}

\begin{abstract}
Lao She is a well-known author in China. His only children modern drama, The Treasure Boat, was adapted from the Chinese folktale and was popular among children in 1962, especially its supporting role the White Cat. It was normal to see animal roles in a children drama, but there was an exception under the situation of the Seventeen years. Animals who are able to talk had been once denied in the early 1950s since Chinese children were summoned by the central government as successors to communism and should have a faithful belief in the realism, following the Soviet. To examine the speciality of the shaping of children roles in this drama, this paper will draw on the narratology theory and historical data research methods to argue that The Treasure Boat's children role shaping was a covert strategy to respond to the summon of the nation and individual humanistic care. Based on The Treasure Boat's original text and historical material, the study concludes that shaping the children character is simultaneously shaping the children audience during the Cold War period. Among the limited research on The Treasure Boat, the adaptation and its reception are of great concern. This study will combine classical narratology with post-classical narratology to the children's drama, providing a new perspective on Lao She, The Treasure Boat and the history of the time.
\end{abstract}

Keywords: Children Drama, Lao She, The Treasure Boat, Cold War.

\section{INTRODUCTION}

Adapted from the Chinese folktale, published in 1961 and performed for four versions since 1962, The Treasure Boat has been in the process of classics, which is the only children modern drama of Lao She. Compared with Lao She's other children literature, The Treasure Boat is special, which is not only because of its Seventeen Year creation background but also the deep structure of the children characters shaping under the contradictory depicts. Unlike the children roles in Xiao Po's Birthday, The Biography of Nui TianCi and Little Wooden Child, The Treasure Boat was not intended to take children as the carrier of the opinion towards the Chinese petty bourgeoisie, racism or nationalism during war times, but seemed to be a positive political response or an individual wish of 'writing for kids' [1]. It can be a contrast with Chen Bochui's Childishness Theory, vehemently denied by the Chinese mainstream in the 1960s.
'The so-called child is not a physical existence, but a methodological concept.' [2]. From the viewpoint of children and children drama, this paper will draw on the classical narratology theory to explore how do The Treasure Boat's shape the children character, also shaping the children audience during the Cold War period.

This study mainly starts from two aspects. On the one hand, there was domestic and multi-cultural children acceptance of The Treasure Boat during the Cold War period. Cases like the actor's record of reflection on the performance, the comment of the time, the memoirs of Bing Xin (another well-known Chinese author) visiting the theatre in Tokyo will support the point that Lao She intentionally or unintentionally shaped the children via his children drama during the Cold War background. One of the remarkable points is that the theme of judging between good and evil demonstrated the characteristics of the times. On the other hand, the 'assistant' White Cat was a significant role who revealed the hidden struggle of Lao She. He transformed children's characteristics from human to animal which appeared to be a safe way. 
Comparing White Cat with the protagonist Wang Erxiao and analyzing their main discourses will provide an entry point to indicate the implied author behind the adult characters and inhuman characters.

\section{LITERATURE REVIEW}

Research explored by Chinese scholars on The Treasure Boat mainly covered the following aspects. The first is to understand the significance of adaptations by exploring the origin of folk literatures and comparing the adaptation versions. The literature by Chen has highlighted motherhood from sources, which gives an indepth interpretation of story types and plays a crucial role in researching expansion [3]. It reveals the origin of folk literature clearly and expounds on the significance of adaptation from different angles. Another is Zhong's research The Adaptation Of The Discussion, standing on the viewer's point of view to express the recognition of the adaptation, raising the importance of children's temperament [4]. On the other hand, different comprehensive research exist in the creation of the drama from appreciating. On the Artistic Features of Lao She 's Children Drama has discussed the emotional connotation, dramatic conflicts, and shaping of characters [5]. Its attention to the connotation meaning behind the Shaping of Negative Characters has an era significance for further study. In On The Pantomime of Lao She, Wu Kaijin, it advocates to pay close attention to children and regard children's needs as creating purpose through analyzing the languages of individuality in drama [6].

The predecessor discovered the unimpressive children drama, carrying out much research, and making considerable progress, but there is still much research in this area of space. The research on Chinese children drama lacks attention to creative methods and themes, which is inseparable from standardization. Although the research of Lao She is more comprehensive in terms of the author and his works, most of them expound in a nutshell and lack attention to the background of the times and excavate of historical materials. In addition, the dissemination of works has not been taken seriously. There are a large number of discussions on the artistic characteristics of the work, but the research method is difficult to break away from the shackles of the text, thereby there is lacking application to new theories. Finally, this drama was created by adults, and after all, the positions of the author and children audience on the text are what we should probe into.

The Treasure Boat has a pivotal position in the history of Chinese children drama and this study follows the method of text interpretation and creatively takes narratology as an important theoretical basis to excavate the profound significance behind the characterization and the shaping of children audience in a specific historical period. The connections between drama and Cold War are what we also attempt to explore.

\section{SHAPING THE CHILDREN AUDIENCE: THE DOMESTICALLY AND MULTI- CULTURAL RECEPTION OF BAO CHUAN DURING THE COLD WAR PERIOD}

In the year of 1955, authoritative publication People's Daily editorialize that the Chinese writers should make more contributions to the enhancement of children's publishing and distributing numbers. Accordingly, Lao She attended the 14th extended meeting of the Presidium of The Chinese Writers Association on October 27 of the same year, discussing issues such as strengthening the leadership of the CPC (Communist Party of China), adjusting institutions and developing children creations.

However, even though the central government kept actively organizing the creation of children's literature, Lao She did not respond to the calling but devoted himself to the language promotion and the Quyi (Chinese folk art forms) creation. Certainly, he had written a few poems, allegro and essays for children constantly, but compared to his production of the same age, the quantity was not substantial until the so-called children's musical drama The Frog Rider was published in 1960. Yet The Frog Rider was far from a children drama because of its language and content which was below the standard Lao She set in 1962: "The children drama should be concise and easy to understand, using few words, and be lively [7]." On $26^{\text {th }}$ August of the same year, Lao She stressed in his report on ethnic minority literature at The Third Literary Congress. "We should adopt a scientific and critical attitude and learn from the literary heritage and excellent folk literature of all ethnic groups". Therefore, it can be inferred that the creation purpose of The Frog Rider was more out of the excavation and protection of folk stories, and the artistic transformation did make this ancient story full of vitality.

The next year, The Treasure Boat was seen in the People Daily, highly up to the standard of Lao She's children drama creation and also in the same sequence of adaption of the folktales like The Frog Rider. On the other hand, it was a truly child-oriented work created at the invitation of from CNTC (China National Theatre for Children). CNTC, formally established on $1^{\text {st }}$ June, 1956, has been shouldering the mission of inheritance and development of children's drama in China, which greatly representing the will of the central government. Its another representative work, The Magic Aster, has been popular in China even until now whereas The Treasure Boat was less known, though some audiences used 'One Flower, One Boat' to describe these two classics. The reasons might be that The Treasure Boat has not been adapted to cross-media forms like films or cartoons and had a much thinner story to get aware by the adults. Nevertheless, it has been influenced the children domestically and internationally in the synchronic sense. 
In the past research on The Treasure Boat, it had been rarely noticed that this only 'standard' children drama of Lao She was once introduced to Japan and gained great attention of the Japanese education. Except for the foundation of civil acceptance since coincidentally, there was a folktale of the same name in Japan, the Cold War background provided the Japanese literary and art circles with sufficient motivation to educate children through a child-friendly form telling them how to distinguish the good from the bad. The bad, at that time, indicated the United States which carried out the commercial and cultural aggression to Japan. The Contaminated Milk Powder Scandal indeed arose the Japanese public's fierce anger, for the United States inhumanely showed its cruelty to the domestic innocent children. Bing Xin quoted the comments of her Japanese friend that the United States exported large quantities of skimmed milk powder to Japan to help the country out of its economic troubles after World War II, but most Japanese could not get used to skimmed milk. Also, when the milk powder was shipped to Japan, it was found to be moldy, containing foreign objects such as lice and coins, and there were cases of children being poisoned after drinking the milk powder.

As mentioned above, although both the United States and Japan belong to the capitalist camp, the relationship between the two has never been a simple "dominantsubordinate" one-way relation, but internal dynamic pluralism. Under this circumstance, Japanese writers translated three versions of The Treasure Boat and promoted it to be on stage. Those original translations are hard to find now, but we can take a closer look at the outline of the translation and reception of The Treasure Ship in Japan via Chinese female children literature writer Bing Xin's reminiscence essay Watching Treasure Ship with Japanese Children [8]. There was a proformance of the translated version of Uchiyama Cargill (Uchiyama brothers were the representatives of the cultural exchanges between China and Japan in twentieth century. Their close relationship with $\mathrm{Lu}$ Xun has attracted the attention of many Chinese modern and contemporary literature researchers) performed by the Tokyo Sunflower Theatre in November 1963. In Bing Xin's recollection, Uchiyama explained the reason for introducing Treasure Ship:

"Japanese children don't know much about the new China. It is very important to introduce Chinese children, especially new Chinese children, to Japanese children about 'universal love'. Chinese writers teach children that to build a new and better society, we must recognize who sympathizes with us and who harms us. The so-called 'philanthropy' should be abandoned [8]."

Bing Xin described a detail when Zhang Busan (Bu means no in Chinese) falsely explained to Wang Erxiao that his "no" was "no stealing, no robbing, no bad", even though the previous situation did not mention whether
Zhang Busan had a criminal record, the children audience had angrily scolded Zhang Busan "you are a bad man!"You are telling a lie, " Bing exclaimed, this indignation voice "consistent with that heard in Beijing's children's theatre." Against the background of the Cold War, Chinese and Japanese children had some kind of spiritual connection. "Overthrow Zhang Busan" also aroused the collective hatred of Japanese children towards American imperialism. Here the central role of Treasure Ship comes into play: children should learn to be vigilant and reveal pretence.

This theme repeatedly reappeared in the Chinese Seventeen Years Literature and Art, revealing the characteristics of the times in a sense. After World War II, the confrontation between the two superpowers intensified, and the rhetoric of ideology was enhanced under the manipulation of psychological warfare. Language and culture became one of the most important weapons in the Cold War. Consequently, using this weapon to train another weapon - the child had become a practical issue. The Soviet Union literary had once fairly stressed out the pedagogical meanings of literary works. Following the same steps, The Treasure Boat had made great efforts to shape the children audience, reflecting the defensive consciousness during the Cold War period.

\section{SHAPING THE CHILDREN CHARACTER: THE TRANSFORMATION OF CHILDNESS FROM HUMAN TO ANIMALS}

Lao She shaped the White Cat image through a bold breakthrough. Compared with the original folktale, Wang Xiaoer, Zhang Busan and Crane all had corresponding prototypes, while the White Cat was an original creation of Lao She. And he was one of the most attractive images in The Treasure Boat and the favourite role of children audiences.

White Cat was highly personified by the genuine cat lover Lao She. He carefully portrayed the laziness and greediness of the White Cat, making his animality vividly unfold through characters.

Two fundamental types of character markedness are introduced in Narrative Fictional including direct definition and indirect expression, the former directly through specific words such as adjectives, abstract nouns or nouns, clearly indicating the characteristics of the characters, and the author has a strong subjective colour. The latter uses "behaviour, parole, appearance, environment" to perform or uses examples to suggest characteristics so that readers can speculate their implied personality. Considering the genre of The Treasure Boat, indirect definition of parole in this shaping method, that is, the dialogue and behaviour between the basis for us to analyze characters. For parole, the work mainly direct points out White Cat's character traits through Wang 
Xiaoer. In the second scene of the first act, the Ant took the initiative to put forward 'looking for work' after being rescued. At this time, Wang Xiaoer compared the behaviours of the White Cat with that of the ant and pointed out the laziness of the White Cat directly. And for behaviour, Lao She uses vivid language to describe the movements of the White Cat, such as he compares it with his eyes that can grow bigger and smaller when introducing the boat. In addition, he often snores in order to drive out the bugs. Cats can change pupil size, firm feet, and snoring. These appearance characteristics and animal habits are naturally integrated into the drama. These details are based on Lao She's careful observation of the cat, making the image of the White Cat quite lively and popular, and the image of the White Cat is shaped in depth through this behaviour and parole. White Cat not only retained the cat's nature but also seemed to be given the vitality of children in the author's works. He had the side of ' laziness ' and 'greediness', and another side of lovely naughty. That could be the reason why he was loved by children.

Children do have the nature of being close to animals and the love mainly points to the similar characteristics between both. In other words, the childishness was shown on the White Cat, including his innocence, humor, and playfulness. However, the joy did not mainly come from himself, but through repeatedly teasing of him. In the second act of his appearance, almost in every dialogue Wang Erxiao indicated the White Cat's shortcomings and jokes about him. For instance, his hesitating for fear of falling into the water was considered timid and was pointed out that there was no sympathy when he laugh at the ant dancing drenched. Even he just did not want to put his tail into the water afraid of being pulled down by the fish, he was evaluated as meanspirited. Obviously, these outspoken 'accusations' were not out of malice in this children's drama. Out of the blame, the setting of the script had a harmonious effect on the contrary.

Wang Xiaoer, as a 'critic', was close to a perfect child image. He was the protagonist of the drama and had a typical positive role. In the adaptation of The Treasure Boat, Lao She strove to show excellent quality through dialogue with other characters. He loves singing and talking with lovely birds. He was kind and full of spiritual beauty, rescuing the near-drowning old man selflessly. Also, he was optimistic and cheerful, leading the animal friends to brave the wind and waves in the face of the flood on the Treasure Boat and never bowing to the force of evil [9]. He set an example of a new communist, constantly calling on other characters to participate actively in home rebuilding. As the guiding role model, the 'good boy'Wang Xiaoer was clearly revealed. But it was strange that a young man of nearly marriageable age had such behavior and childish language, he excluded the intention to achieve artistic effects and be close to children. However, his behavior such as taking charge of a department alone and committing to the family is far beyond the maturity of children and conflicts with the character set, which was the reason why he could not marry the princess at once as the prototype story but end by beating about the bush. This study regards it as a minor flaw of the drama but more confirm that Wang Xiaoer was an ideal child who has completed. By contrast, the White Cat as an assistant having all sorts of imperfections was the object of educating. From this point of view, the White Cat was close to the children audiences and he had a natural desire for food and fun. But he was also suppressed by the sudden situation like the critical flood and was called for growing immediately and sparing no effort to work.

From laziness and naughty to being engaged in work, it was not only the calling of Wang Xiaoer that made the White Cat change and grow up. Under such a transformation, it seems that someone exists in the drama objectively and acts as a hidden guide and educator which is also called 'implicit author' and 'the author alter ego' [10]. On the one hand, the portrait of the characters obtained by the audience on it is one of the author's most important effects. The author enables the children audience to be educated through the characterization of the characters unconsciously. On the other hand, 'the implied author' is related to the author [11]. In The Treasure Boat, the close relationship between them lies in Lao She. He intends to make children escape from the preachment temporarily and resonate with the children audience.

To sum up, the image of the White Cats expressed the affection of Lao She for cats and polished the drama to be more intresesting and informative. In addition, though the White Cat was not human or a perfect child, he was the closest to that of in Lao She's heart which was more similar to the image of children in other works of Lao She. Children could stop for a while with the White Cat before becoming a child-like Wang Xiaoer that might be exactly what Lao She hoped for.

\section{CONCLUSION}

Overall, The Treasure Boat was not outstanding in Lao She's overall creation, but it left a meaningful mark in Chinese children's drama, and also made a footnote for the political and historical background of the Cold War at home and abroad. The Treasure Boat reflected the continuity of the "discovery of children" as a political propaganda discourse since the "May 4th Movement", that is, the "discovery" of children did not lie in their significance as "people", but in their potential before reaching adulthood. In the seventeen years of literature and art, such potential was condensed into some images of "perfect children" like Wang Erxiao, while the real child nature was transferred to the animals that could speak for artistic presentation, so as to avoid criticism -- 
which indeed summarized the situation of children in China in the 1950s and 1960s in a sense.

\section{REFERENCES}

[1] Shu Y. My Father Lao She [M]. Liaoning People Press, 2008: 167.

[2] Karatani K., Origins of Modern Japanese Literature, Central Compilation \& Translation Press $[\mathrm{M}]$, 2013:104.

[3] Cheng N. The Origin and Dissemination of Folk Literature of The Treasure Boat [J]. Journal of Hainan Normal University (Social Science Edition), 2020, 33 (05) : 9-16.

[4] Zhong Z.M. The adaptation of The Treasure Boat [J]. Shanghai Drama, 1962 (08) : 19-20.

[5] Ling Y.G..The artistic characteristics of Lao She 's children drama [ $\mathrm{J}$ ].Journal of Hunan Mass Media Vocational and Technical College, 2014 ( 04 ) : 6668.

[6] Wu K.J. Lao She 's fairy tale [ J ]. Qilu Journal (03) :115-118.

[7] Lao She. Have an Outstanding Eloquence [M]. Shanghai: Fudan University Press.2004: 37.

[8] Bingxin. Bing xin Corpora 6 [M]. Straits Literature and Art Publishing House. 1994: 362-365.

[9] Limon K. Yao J.Q. Narrative Fiction [M]. Life Reading Xinzhi Sanlian Bookstore, 1989.

[10] Seymour C. Story and discourse [M]. People's University of China Press, 2013.

[11] Seymour C. Story and discourse [M]. People's University of China Press, 2013. 